\title{
Cathepsin B is activated as an executive protease in fetal rat alveolar type II cells exposed to hyperoxia
}

\author{
Hyeon-Soo Lee ${ }^{1,2,5}$ and Chun-Ki Kim ${ }^{3,4}$ \\ ${ }^{1}$ Department of Pediatrics \\ Kangwon National University Hospital School of Medicine \\ ${ }^{2}$ Institute of Medical Sciences \\ Kangwon Naitonal University School of Medicine \\ Chuncheon 200-947, Korea \\ ${ }^{3}$ Medical and Bio-Materials Research Center \\ ${ }^{4}$ Department of Molecular and Cellular Biochemistry \\ Kangwon National University School of Medicine \\ Chuncheon 200-701, Korea \\ ${ }^{5}$ Corresponding author: Tel, 82-33-258-2318; \\ Fax, 82-33-258-2418; E-mail, premee@kangwon.ac.kr \\ DOI 10.3858/emm.2011.43.4.027 \\ Accepted 15 March 2011 \\ Available Online 18 March 2011
}

Abbreviations: $\mathrm{AV}$, annexin $\mathrm{V}$; $\mathrm{CB}$, cathepsin $\mathrm{B}$; $\mathrm{CBI}$, cathepsin B inhibitor; E19, embryonic day 19; FATIIC, fetal alveolar type II cell; LDH, lactate dehydrogenase; PI, propidium iodide

\begin{abstract}
Alveolar type II cells are main target of hyperoxia-induced lung injury. The authors investigated whether lysosomal protease, cathepsin B (CB), is activated in fetal alveolar type II cells in the transitional period from the canalicular to saccular stages during 65\%-hyperoxia and whether CB is related to fetal alveolar type II cell (FATIIC) death secondary to hyperoxia. FATIICs were isolated from embryonic day 19 rats and exposed to $65 \%$-oxygen for $24 \mathrm{~h}$ and $36 \mathrm{~h}$. The cells exposed to room air were used as controls. Cell cytotoxicity was assessed by lactate dehydrogenase-release and flow cytometry, and apoptosis was analyzed by TUNEL assay and flow cytometry. CB activity was assessed by colorimetric assay, qRT-PCR and western blots. $65 \%$-hyperoxia induced FATIIC death via necrosis and apoptosis. Interestingly, caspase-3 activities were not enhanced in FATIICs during 65\%-hyperoxia, whereas $\mathrm{CB}$ activities were greatly increased during 65\%-hyperoxia in a time-dependent manner, and similar findings were observed with qRT-PCR and western blots. In addition, the preincubation of CB inhibitor prior to $65 \%$-hyperoxia reduced FATIIC death significantly. Our studies suggest that CB activation
\end{abstract}

secondary to hyperoxia might have a relevant role in executing the cell death program in FATIICs during the acute stage of $65 \%$-hyperoxia.

Keywords: caspase-3; cathepsin B; cell death; fetal alveolar type II cell; hyperoxia

\section{Introduction}

A high concentration of oxygen is a main stay in preterm infants with respiratory distress since birth. However, exposure to a high concentration of oxygen $(>40 \%)$ for prolonged periods causes lung injuries, which is a major contributing factor to the development of bronchopulmonary dysplasia (Barazzone et al., 2000; O'Reilly et al., 2000; Ward et al., 2000).

Alveolar type II cells act as stem cells for alveolar epithelial restoration after lung injuries and during normal tissue turnover (Rama et al., 1997) and must be the critical target of hyperoxia-induced lung injury. Moreover, hyperoxia has the major biological effect of cell death, which contributes to the genesis of hyperoxia-induced lung injuries (Lee and Choi, 2003).

For many years, apoptosis of alveolar type II cells has been regarded as a critical event in the development of lung injuries (Perl et al., 2005). However, there have been some evidences that showed the morphological changes of alveolar epithelial cells during hyperoxia generally presented necrotic (Kroemer et al., 1998; Barazzone et al., 1999; Mantel and Lee, 2000; Saraste and Pulkki, 2000; Strasser et al., 2000; Martin et al., 2003, 2005) or overlapping features of apoptosis (Warner et al., 1998). Therefore, more attention is required to define the mechanisms that induce alveolar type II cell death during hyperoxia.

Currently there has been a growing concern of caspase-independent cell death via non-caspase protease released through lysosomal permeabilization. In particular, the role of $C B$ in inducing cell death has been revealed in other cell lines and conditions (Layton et al., 2001; Bröker et al., 2004; Tang et al., 2006). Although oxygen radical species generated by hyperoxia is a stimulus for lysosomal permeabilization, whether FATIIC death is mediated by the non-caspase protease, $C B$, has never been explored yet. 
A

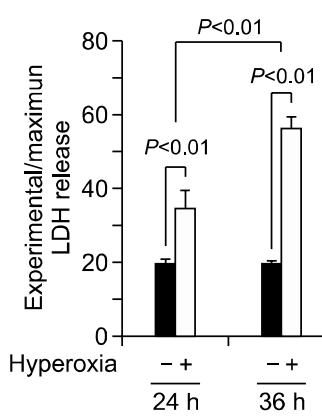

B

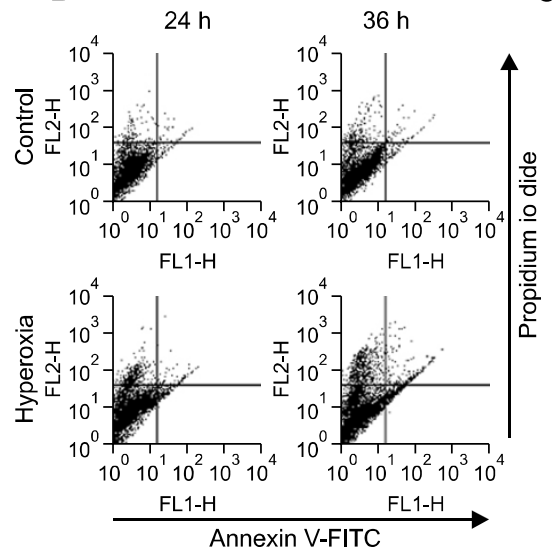

C

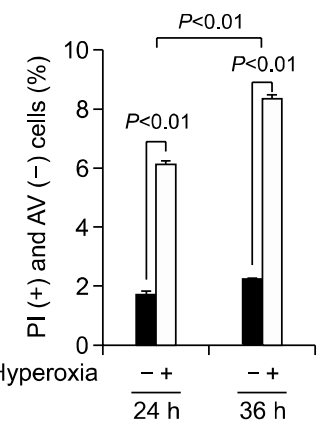

Figure 1. Effect of 65\%-hyperoxia on FATIIC cytotoxicity. (A) Graphical depiction showing LDH-release expressed as experimental minus background LDH-release divided by the maximum LDH-release in hyperoxic and normoxic cells. Results are means \pm SD from 3 different experiments. (B) Graphical depiction showing distribution of necrosis and apoptosis evaluated by AV and PI staining in hyperoxic and normoxic cells. (C) Graphical depiction showing pure necrosis (PI-positive, AV-negative) as a percentage of the total cell number in hyperoxic and normoxic cells. Results are mean \pm SD from 3 different experiments.

In this study, the authors investigated whether CB was activated in FATIICs on day E19 of gestation (transition from canalicular to saccular stages of lung development) during hyperoxia and whether CB was related to FATIIC death using an in vitro model system.

\section{Results}

\section{Effect of 65\%-hyperoxia on FATIIC cytotoxicity}

Cell lysis analyzed by LDH-release into the supernatant significantly increased 1.8-fold after 24 $\mathrm{h}$ of hyperoxia (control $=19.8 \pm 1.2 \mathrm{vs}$. hyperoxia $=34.9 \pm 4.8 ; P<0.01$ ) and 2.8-fold after $36 \mathrm{~h}$ of hyperoxia (control $=20.0 \pm 0.3$ vs. hyperoxia $=$ $56.2 \pm 3.0 ; \quad P<0.01)$ when compared to the controls (Figure 1A). As shown in Figure 1B, 65\%hyperoxia caused a modest increase in cellular necrosis, as measured by the selective increase in propidium iodide $(\mathrm{PI})$ staining (Bhandari et al., 2006) after $24 \mathrm{~h}$ and $36 \mathrm{~h}$ (Figure 1B), and the percentage of cells undergoing pure necrosis [PI-positive and Annexin V(AV)-negative] (Bhandari et al., 2006) significantly increased in hyperoxic cells $(24 \mathrm{~h}$-control $=1.7 \pm 0.11$ vs. $24 \mathrm{~h}$-hyperoxia $=6.2 \pm 0.06 ; P<0.01 ; 36$ h-control $=2.2 \pm 0.03$ vs. 36 h-hyperoxia $=8.4 \pm 0.10 ; P<0.01$ ) when compared to the control samples (Figure 1C).

\section{Effect of 65\%-hyperoxia on FATIIC apoptosis}

DNA fragmentation assessed by TUNEL assay showed that $65 \%$-hyperoxia increased the apop-
A
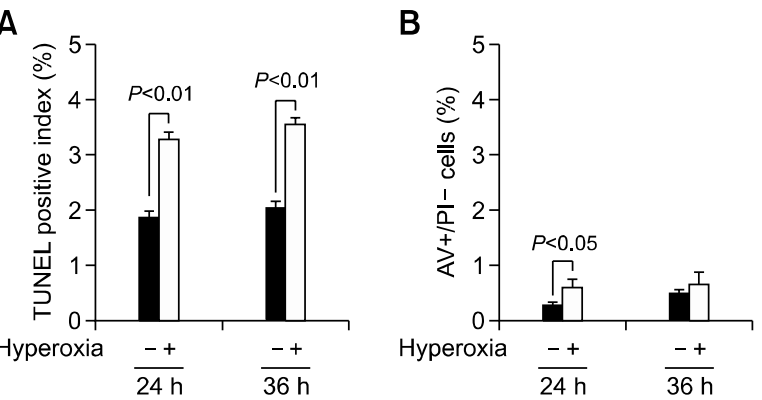

Figure 2. Effect of 65\%-hyperoxia on FATIIC apoptosis. (A) Graphical depiction showing detection and quantification of DNA fragmentation analyzed by TUNEL assay in hyperoxic and normoxic cells. Results are mean \pm SD from 3 different experiments. (B) Graphical depiction showing apoptotic cells (AV-positive) as a percentage of the total cell number in hyperoxic and normoxic cells. Results are mean \pm SD from 3 different experiments.

tosis index 1.7-fold after $24 \mathrm{~h}$ (control $=1.9 \pm 0.12$ vs. hyperoxia $=3.3 \pm 0.10 ; P<0.01$ ) and 1.8 -fold after $36 \mathrm{~h}$ (control $=2.0 \pm 0.12$ vs. hyperoxia $=3.6$ $\pm 0.12 ; P<0.01$ ) when compared to the controls (Figure 2A). As shown in Figure 2B, the percentage of cells undergoing early apoptosis [AVpositive] during 65\%-hyperoxia did not increase greatly $(24 \mathrm{~h}$-control $=0.3 \pm 0.04$ vs. 24 h-hyperoxia $=0.6 \pm 0.13, P<0.05 ; 36 \mathrm{~h}$-control $=0.5 \pm$ 0.06 vs. 36 h-hyperoxia $=0.8 \pm 0.69)($ Figure $2 \mathrm{~B})$.

\section{Effect of $65 \%$-hyperoxia on caspase-3 activity in FATIICs}

Cleaved caspase- 3 is a key executioner protein in apoptosis. Caspase- 3 activity was analyzed by 

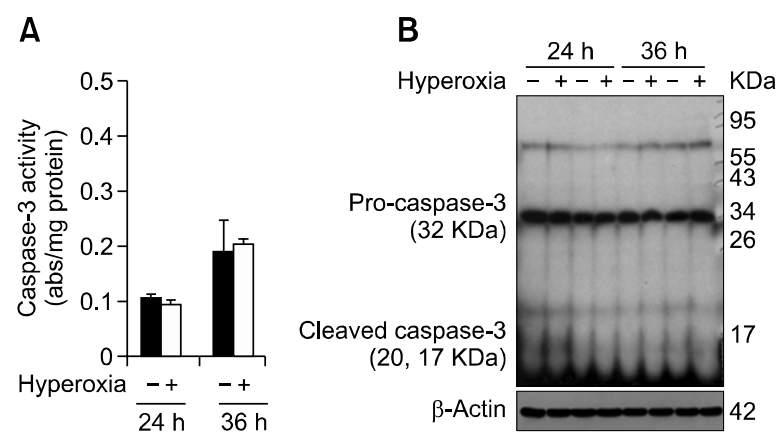

Figure 3. Effect of $65 \%$-hyperoxia on caspase-3 activity in FATIICs. (A) Graphical depiction showing that $65 \%$-hyperoxia for $24 \mathrm{~h}$ and $36 \mathrm{~h}$ does not increase caspase-3 activity in FATIls compared to the control samples. Results are the mean \pm SD from 3 different experiments. (B) Western blots showing that the exposure of E19 cells to 65\%-hyperoxia for $24 \mathrm{~h}$ and $36 \mathrm{~h}$ does not increase the levels of active (cleaved) caspase-3 and concomitantly does not decrease the abundance of full-length procaspase-3 compared to the control samples.

colorimetric activity assay upon cell lysis. 65\%hyperoxia did not increase cleaved caspase- 3 in FATIICs at $24 \mathrm{~h}$ (Control $=0.12 \mathrm{Abs} / \mathrm{mg}$ protein $/ \mathrm{h}$ \pm 0.12 vs. Hyperoxia $=0.10 \mathrm{Abs} / \mathrm{mg}$ protein $/ \mathrm{h} \pm$ 0.01 ) and $36 \mathrm{~h}$ (Control $=0.20 \mathrm{Abs} / \mathrm{mg}$ protein $/ \mathrm{h} \pm$ 0.07 vs. Hyperoxia $=0.21 \mathrm{Abs} / \mathrm{mg}$ protein $/ \mathrm{h} \pm$ 0.01 ) compared to the controls (Figure $3 \mathrm{~A}$ ). The positive criterion in these experiments was 1.2 $\mathrm{Abs} / \mathrm{mg}$ protein/h. In addition, western blots were done for the two different experimental sets. The western blots for caspase- 3 showed that $65 \%$ hyperoxia did not enhance the level of cleaved caspase-3 compared to the control samples and concomitantly did not decrease the abundance of full-length procaspase-3 (Figure 3B).

\section{Effect of 65\%-hyperoxia on CB activity in FATIICs}

Activity of $\mathrm{CB}$ was analyzed by fluorescence-based assay upon cell lysis. The results showed that $65 \%$-hyperoxia increased the CB activity 1.8 -fold at $24 \mathrm{~h}$ (Control $=5336 \pm 960$ vs. Hyperoxia $=9611$ $\pm 1691, P<0.05$ ) and 2.6 -fold at $36 \mathrm{~h}$ (Control $=$ $6334 \pm 716$ vs. Hyperoxia $=16612 \pm 2252, P<$ 0.05), respectively in FATIICs compared to the controls (Figure 4A). As shown in Figure 4B, $65 \%$-hyperoxia increased the $\mathrm{CB}$ mRNA expression 1.3-fold at $24 \mathrm{~h}$ (Control $=1.08 \pm 0.04$ vs. Hyperoxia $=1.41 \pm 0.01, P<0.05)$ and 1.8 -fold at $36 \mathrm{~h}$ (Control $=0.92 \pm 0.04$ vs. Hyperoxia $=1.64$ $\pm 0.06, P<0.05)$ in FATIICs compared to the controls (Figure 4B). Western blots done for the two different experimental sets showed that $C B$ was enhanced greatly in a time-dependant manner in FATIICs during $65 \%$-hyperoxia compared to the controls (Figure $4 \mathrm{C}$ ).
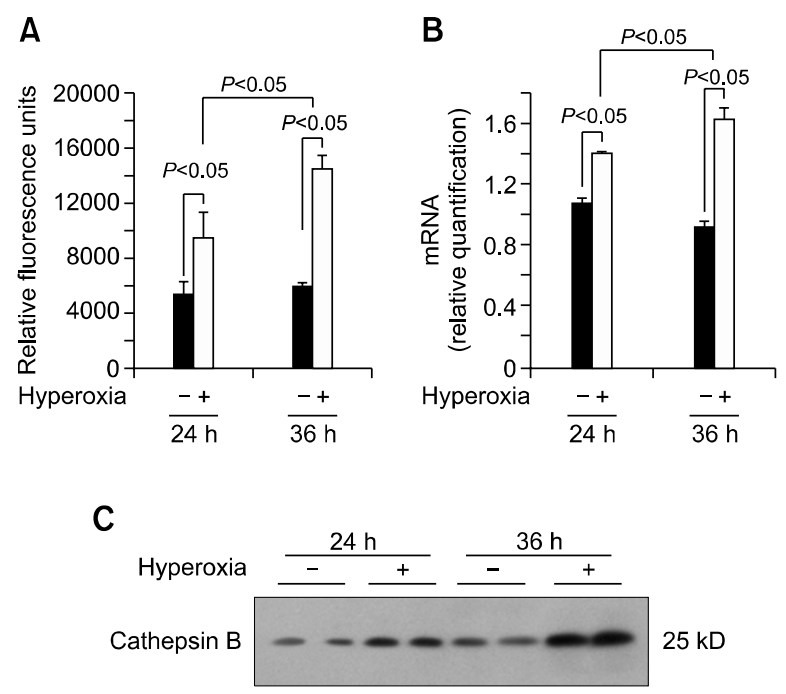

Figure 4. Effect of 65\%-hyperoxia on CB activity in FATIICs. (A) Graphical depiction showing that $65 \%$-hyperoxia for $24 \mathrm{~h}$ and $36 \mathrm{~h}$ increases $C B$ activity significantly compared to the control samples. Results are the mean \pm SD from 3 different experiments. (B) Graphical depiction showing that $65 \%$-hyperoxia for $24 \mathrm{~h}$ and $36 \mathrm{~h}$ upregulates $\mathrm{CB}$ gene expression significantly compared to the control samples. Results are mean $\pm S D$ from 3 different experiments. (C) Western blots showing that $65 \%$-hyperoxia for $24 \mathrm{~h}$ and $36 \mathrm{~h}$ enhances the levels of CB compared to the control samples.

\section{Effect of preincubating FATIICs with CB inhibitor (CBI)}

Based on previous findings which showed that $65 \%$-hyperoxia increased cell death and CB activity, the authors evaluated whether preincubation of $\mathrm{CBI}$ prior to hyperoxia inhibits FATIIC death. E19 FATIICs were incubated with specific inhibitor of CB, CA074Me (Calbiochem, San Diego, $\mathrm{CA}$ ), at a concentration of $100 \mu \mathrm{M}$ for $1 \mathrm{~h}$ (Bröker et al., 2004) prior to exposure to 65\%-hyperoxia. As shown in Figure $5 \mathrm{~A}$, preincubated FATIICs using $\mathrm{CBI}$ had a decreased cell cytotoxicity (as measured by LDH-release) of $34 \%$ at $24 \mathrm{~h}$ compared to the untreated cells (Untreated $=$ $34.9 \% \pm 4.78$ vs. Treated $=23.0 \% \pm 4.58, P<$ 0.05 ) and $37 \%$ at $36 \mathrm{~h}$ compared to the cells without CBI treatment (Untreated $=56.2 \% \pm 3.05$ vs. Treated $=35.3 \% \pm 2.52, P<0.01)$. Additionally, as shown in Figure $5 \mathrm{~B}$, TUNEL-positive cells decreased by $15 \%$ at $24 \mathrm{~h}$ in the treated cells compared to the untreated cells (Untreated $=3.4 \%$ \pm 0.42 vs. Treated $=2.9 \% \pm 0.21, P<0.05$ ), and decreased by $18 \%$ at $36 \mathrm{~h}$ in the treated cells compared to the untreated cells (Untreated $=3.6 \%$ \pm 0.42 vs. Treated $=3.0 \% \pm 0.14, P<0.05)$. 

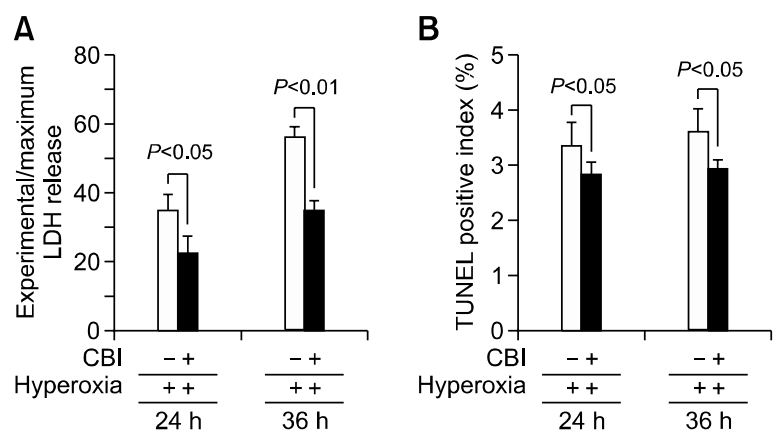

Figure 5. Effect of preincubating FATIICs with $\mathrm{CBI}$ prior to $65 \%$ hyperoxia. E19 type II cells were preincubated with a specific inhibitor of $\mathrm{CB}, \mathrm{CA} 074 \mathrm{Me}$ at a concentration of $100 \mu \mathrm{M}$ for $1 \mathrm{~h}$ before applying $65 \%$-hyperoxia. Samples in hyperoxic and normoxic conditions were processed to assess LDH-release into the supernatant (A) and TUNEL positive index (B). Results with $\mathrm{CBI}$ were compared to samples without the inhibitor. Results are mean \pm SD from 3 different experiments.

\section{Discussion}

The main findings of the present study is that FATIIC death was induced via necrosis and apoptosis during the acute stage of $65 \%$-hyperoxia, and only $C B$, not caspase-3, was enhanced remarkably in a time-dependent manner in FATIICs during $65 \%$-hyperoxia, and preincubaiton of FATIICs with $\mathrm{CBI}$ prior to hyperoxia attenuated FATIIC death significantly. Therefore, these results suggest that $\mathrm{CB}$ might have a relevant role in executing cell death in FATIICs during the acute stage of $65 \%$ hyperoxia.

In our investigations, we selected $65 \%$-hyperoxia, based on previous observation showing that $65 \%$ hyperoxia exposure to newborn mice caused impairment of lung architecture in adult mice (Dauger et al., 2003). Therefore, in the current study, we investigated whether 65\%-hyperoxia induces any injurious effect to FATIICs that are key components of the alveolar structure.

The important feature of hyperoxia-induced lung injury is alveolar cell death (Lee and Choi, 2003). Our investigations showed that 65\%-hyperoxia induced FATIIC death via necrosis and apoptosis. However, cell cytotoxicity analyzed by LDH-release was significantly increased in a time-dependent fashion, and similar findings were observed with the FACS analysis, whereas TUNEL-positive cells observed during 65\%-hyperoxia ranged from $3.3-3.6 \%$, and early apoptotic cells assessed by FACscan were $<1 \%$ during $65 \%$-hyperoxia, which was not significantly different from the values observed in the control samples. Based on the fact that apoptosis in the range $0-3 \%$ is a physiological event (Scavo et al., 1998; Sanchez-Esteban et al., 2002), in the recent observation, apoptotic cells did not increase remarkably in FATIICs during 65\%hyperoxia for $36 \mathrm{~h}$. The present data in terms of cell cytotoxicity and apoptosis are similar to previous observations showing that $\mathrm{LDH}$-release was increased by around 4-fold at $12 \mathrm{~h}$ in A549 cells exposed to $95 \%$-hyperoxia compared to normoxic cells (Rhaman et al., 2001), while apoptosis index assessed by TUNEL assay was decreased by $50 \%$ in human fetal epithelial cells exposed to 95\%-hyperoxia compared to normoxic cells (Bustani et al., 2006). On the other hand, TUNEL-positive cells observed in the current study had some discrepancies compared to observations in other studies, where a high TUNEL-positive index (70$85 \%$ ) were seen in cultured rat type II cells at day $19.5 \mathrm{E}$ or E21 exposed to lethal hyperoxia (85-95\% oxygen) (Haaften et al., 2009; Huang et al., 2009). In addition, according to previously published data, apoptotic activities showed an oxygen dose dependency proportional to the amount of oxidants generated, and lower concentrations of $\mathrm{H}_{2} \mathrm{O}_{2}$ did not induce TUNEL-positive apoptosis, only cell swelling, while intermediate doses of oxidants induce mixed modes of cell death with some dying by apoptosis and some by cell swelling (Ueda and Shah, 1992; Iwata et al., 1994; Slater et al., 1995). In addition, these discrepancies may be partly due to the different doses of oxygen exposure and different experimental conditions including the plates used and cellular confluency obtained.

Up until now, it has not been clearly defined whether hyperoxia induces primarily apoptotic or non-apoptotic death in vivo and in vitro. Taking into consideration of the present data, FATIICs are presumed to undergo cell death generally via necrosis rather than apoptosis during the acute stage of $65 \%$-hyperoxia, and apoptosis might affect just a minority of the cell population. Our observations are partly supported by previous observation showing that epithelial cells generally show necrotic feature during hyperoxia (Kroemer et al., 1998; Barazzone et al., 1999; Mantel and Lee, 2000; Saraste and Pulkki, 2000; Strasser et al., 2000; Martin et al., 2003, 2005).

Our results showed that caspase-3 was not enhanced in FATIICs during 65\%-hyperoxia. Previously, similar findings were found in human fetal alveolar epithelial cells exposed to 95\%-hyperoxia (Bustani et al., 2006) and in human lung epithelial cells stimulated by lipopolysaccharide (Tang et al., 2006). Although, for many years, injury of alveolar epithelial cells has mainly focused on the caspases as the executioners of apoptosis (Guicciard et al., 2004), the current observation regarding caspase-3 suggests that during 65\%-hyperoxia, caspases could prevent their own activation resulting in 
apoptosis in FATIICs so it could be possible that $65 \%$-hyperoxia might trigger a caspase-independent apoptotic pathway.

In a recent study, non-caspase proteolytic enzyme, $\mathrm{CB}$, was enhanced greatly in a time-dependant manner in FATIICs during 65\%-hyperoxia, and its increases were proportional to the increases in FATIIC death. Since previously published reports address that $C B$ mediates human lung epithelial cell death stimulated by lipopolysaccharides (Tang et al., 2006) or human lung endothelial cell death in allergic lung inflammation (Layton et al., 2001) or cell death in tumor cell lines (Bröker et al., 2004), our investigation implicates that $C B$ may play a dominant role in executing FATIIC death under the condition of hyperoxia as well.

Lysosomal permeabilization is a critical step in caspase-independent cell death, which can be induced by reactive oxygen radicals generated by hyperoxia (Guicciard et al., 2004). CB, which is ubiquitously expressed and most abundant in lysosomes (Guicciard et al., 2004), is released through lysosomal permeabilization. Hence, it is presumed that $C B$ released through lysosomal permeabilization may induce cellular necrosis and apoptosis depending on the magnitude of lysosomal permeabilization.

Moreover, in the current study, preincubation with $\mathrm{CBI}$ prior to $65 \%$-hyperoxia did attenuate FATIIC death significantly. These results indicate that $\mathrm{CB}$ is related to FATIIC death secondary to $65 \%$-hyperoxia.

Our study has the limitations inherent to an in vitro experimental system in which E19 type II cells were isolated from their environment. Hence, further exploration is required in an in vivo model of bronchopulmonary dysplasia.

In summary, our in vitro results suggest that $65 \%$-hyperoxia induces FATIIC death via necrosis and apoptosis with a higher magnitude of necrosis, and $C B$, not caspase- 3 , is enhanced greatly proportionally to the increase in FATIIC death during $65 \%$-hyperoxia for $36 \mathrm{~h}$, which implies that a caspase-independent pathway mediated by $\mathrm{CB}$ might be a potential mechanism to induce FATIIC death during the acute stage of $65 \%$-hyperoxia. In addition, such better understanding of the mechanisms to induce FATIIC death during hyperoxia may lead to the development of novel therapeutic strategies for augmenting lung injury in preterm lungs.

\section{Methods}

\section{Cell isolation, hyperoxia and treatment procedure}

Fetal rat lungs were obtained from time-pregnant SpragueDawley rats (Daehan Biolink, Eumsung, South Korea) on E19 (term = 22 days), and E19 type II cells were isolated as previously described (Sanchez-Eesteban et al., 2006). Briefly, after collagenase digestion, cell suspensions were sequentially filtered through $100-, 30-$, and $20-\mu \mathrm{m}$ nylon meshes using screen cups (Sigma Chemical Co., St. Louis, MO). The filtrate from $20-\mu \mathrm{m}$ nylon mesh, containing mostly fibroblasts, was discarded. Clumped non-filtered cells from the 30- and 20- $\mu \mathrm{m}$ nylon meshes were collected with DMEM (Dulbecco's Modified Eagle Medium) to facilitate filtration of non-epithelial cells. Further FATIIC purification was achieved by incubating cells in $75-\mathrm{cm}^{2}$ flasks for $30 \mathrm{~min}$. Non-adherent cells were collected and cultured overnight. Purity of the FATIIC fraction was determined to be $90 \pm 5 \%$ by microscopic analysis of epithelial cell morphology and immune-blotting for cytokeratin/ surfactant protein- $C$ and vimentin as markers of epithelial cells and fibroblasts respectively (Sanchez-Esteban et al., 2004). After overnight culture, FATIICs were harvested with trypsin and plated at a density of $10 \times 10^{5}$ cells/well on 6 -well plates precoated with laminin $[10 \mu \mathrm{g} / \mathrm{ml}]$. Plates were incubated in a culture chamber with ProOx Oxygen Controller with Low profile right angle sensor (BioSpherix, Redfiled, NY) under 65\%-hyperoxia for $24 \mathrm{~h}$ and $36 \mathrm{~h}$. Cells grown in normoxia $\left(5 \%-\mathrm{CO}_{2}\right)$ were treated in an identical manner and served as controls. For inhibition studies, the cells in one group were preincubated with specific inhibitor of CB, CA074Me (Calbiochem, San Diego, $\mathrm{CA}$ ), at a concentration of $100 \mu \mathrm{M}(20)$ for $1 \mathrm{~h}$ prior to $65 \%$-hyperoxia, and the cells in another group were exposed to $65 \%$-hyeproxia without the inhibitor.

\section{Lactate dehydrogenase assay}

LDH-release into the supernatant upon cell lysis was measured using a CytoTox $96^{\mathbb{R}}$ non-radioactive cytotoxicity assay (Promega, Madison, WI), according to the manufacturer's protocol. The cytotoxicity was measured as \% cytotoxicity [experimental LDH-release (OD490) per maximal LDH-release (OD490)]. Absorbance at wavelength 490 $\mathrm{nm}$ was collected using a 96-well plate reader (Ultraspec 2100 pro, Amersham Pharmacia Biotech, Amersham, UK).

\section{FACS analysis}

FACS analysis was performed using an Annexin V-FITC apoptosis kit (BD Pharmingen, Franklin Lakes, NJ). Cells in trypsin were resuspended in $1 \times$ Binding Buffer, and $5 \mu \mathrm{l}$ of FITC Annexin $V$ and propidium iodide were added. After incubation in the dark, $400 \mu$ of $1 \times$ binding buffer was added, and the cells were analyzed by flow cytometry (Becton Dickinson, Franklin Lakes, NJ).

\section{TUNEL assay}

Detection and quantification of apoptotic cells were performed using terminal deoxynucleotidyl transferase-mediated 
dUTP-FITC nick-end labeling (TUNEL) by a fluorescein lable apoptosis detection system (Promega, Madison, WI) according to the manufacturer's instructions. E19 monolayers fixed in $4 \%$ paraformaldehyde in PBS were permeabilized by immersion in $2.0 \%$ Triton X-100 in PBS. Monolayers were incubated in equilibration buffer, 2deoxynucleotide 5'-triphosphate, and terminal deoxynucleotidyltransferase (TdT) enzyme. A control was prepared by omitting the TdT enzyme. After washing with $1 \times$ PBS, samples were mounted with Vectashield mounting medium with PI (Vector Laboratories, Burlington, CA) and analyzed by fluorescence microscopy. For quantification of apoptotic cells, 50 high-power fields per sample were analyzed. Results were expressed as TUNEL positive index (number of TUNEL positive cells per number of total cells).

\section{Caspase- 3 activity assay}

Caspase-3 activity was analyzed by colorimetric activity assay (Chemicon ${ }^{\circledR}$ International, Temecula, USA) upon cell lysis. The cells in $1 \times$ lysis buffer were incubated, and the supernatant was obtained. Caspase- 3 activity was evaluated by measuring proteolytic cleavage of chromogenic substrate Ac-DEVD-pNA used as the substrates for caspase-3-like proteases (Kim et al., 2000). Cell lysate (60 $\mu \mathrm{g}$ of protein) was added into buffer A containing 150 $\mathrm{mmol} / \mathrm{L}$ Ac-DEVD-pNA in a final volume of $150 \mu \mathrm{l}$. After incubation, the increase in absorbance of enzymatically released pNA was measured at $405 \mathrm{~nm}$ in a microplate reader every $10 \min$ for $2 \mathrm{~h}$.

\section{Western blot of caspase-3 and CB}

Monolayers were lysed in RIPA buffer $(20 \mathrm{mM}$ Tris- $\mathrm{HCl}[\mathrm{pH}$ 8.0], $137 \mathrm{mM} \mathrm{NaCl}, 1 \%$ Triton X-100, 10\% glycerol, $2 \mathrm{mM}$ EDTA, $1 \mathrm{mM}$ sodium vanadate, $1 \mathrm{M} \beta$-glycerophosphate, $0.5 \mathrm{M}$ sodium fluoride, $1 \mathrm{mM}$ phenylmethylsulfonyl fluoride). Lysates were centrifuged and total contents were determined using BCA protein assay kit. $50 \mu \mathrm{g}$ of protein were separated by SDS-PAGE and transferred to polyvinylidene difluoride membranes. Blots were hybridized with polyclonal antibody against the 11/17/20-kDa cleaved caspase-3 and $32-\mathrm{kDa}$ full-length procaspase-3 (Santa Cruz Biotechnology, Santa Cruz, CA), or against the 25-kDa activated CB (Santa Cruz Biotechnology, Santa Cruz, CA). Secondary antibody was conjugated with horseradish peroxidase, and blots were developed by exposing them to X-ray film. Membranes were then stripped and reprobed with actin antibody, and processed as described previously in this manuscript.

\section{CB activity assay}

CB activity was measured using CB Assay Kit (BioVision, Mountain View, CA), according to the manufacturer's protocol. Supernatant was obtained from the cells in CB lysis buffer. $50 \mu \mathrm{l}$ of CB reaction buffer and $2 \mu \mathrm{l}$ of $10 \mathrm{mM}$ CB substrate were added. After incubation, the mixture was read in a fluorometer at 400-nm excitation and 505$\mathrm{nm}$ emission. CB activity was determined by comparing the relative fluorescence units (RFU) with the level of the control samples.

\section{Real-time PCR (qRT-PCR) of CB}

Total RNA was extracted from E19 FATIICs exposed to $65 \%$-hyperoxia for $24 \mathrm{~h}$ and $36 \mathrm{~h}$ or parallel normoxic samples by a single-step method, as previously described (Sanchez-esteban et al., 1998) and purified further with the Rneasy Mini Kit (Invitrogen, Carlsbad, CA). Fold expressions of hyperoxic samples relative to controls were calculated using the $\Delta \Delta C_{T}$ method for relative quantification (RQ). As previously described (Wang et al., 2006). Samples were normalized to the 18S rRNA. TaqMan primers from Assays-on-Demand ${ }^{\mathrm{TM}}$ Gene Expression Products (Applied Biosystems, Carlsbad, CA) and the following primers were used: CB (cat. \#: Rn00575030_m1) and 18S (cat. \#: Hs99999901_s1). $5 \mu \mathrm{g}$ of total RNA were reverse-transcribed into cDNA by the Superscript Double Stranded cDNA Synthesis kit (Invitrogen, Carlsbad, CA). To amplify the cDNA by qRT-PCR, $5 \mu \mathrm{l}$ of cDNA were added to a mixture of $25 \mu$ of TaqMan Universal PCR Master Mix (Applied Biosystems, Carlsbad, CA) and $2.5 \mu \mathrm{l}$ of 20 x Assays-on-Demand ${ }^{\mathrm{TM}}$ Gene Expression Assay Mix containing forward and reverse primers and TaqManlabeled probe (Applied Biosystems, Carlsbad, CA). Reactions were performed in an $A B I$ Prism 7000 Sequence Detection System (Applied Biosystems, Carlsbad, CA).

\section{Statistical analysis}

Results are expressed as means \pm SD from three experiments, using different litters for each experiment. For intergroup comparisons, data were analyzed with unpaired Student's $t$-test. A $P$-value $<0.05$ was considered statistically significant.

\section{Acknowledgements}

HS Lee was supported by a grant from National Research Foundation (NRF) (grant No. 0808044-1-1), South Korea.

\section{References}

Barazzone C, Donati YR, Rochat AF, Vesin C, Kan CD, Pache JC, Piguet PF. Keratinocytes growth factor protects alveolar epithelium and endothelium from oxygen induced injury in mice. Am J Pathol 1999;154:1479-87

Barazzone $C$, White CW. Mechanisms of cell injury and death in hyperoxia: role of cytokines and Bcl-2 family proteins. Am J Respir Cell Mol Biol 2000;22:517-9

Bhandari V, Choo-Wing R, Lee CG, Zhu Z, Nedrelow JH, Chupp GL, Zhang X, Matthay MA, Ware LB, Homer RJ, Lee PJ, Geick A, de Fougerolles AR, Elias JA. Hyperoxia causes angiopoietin 2-mediated acute lung injury and necrotic cell death. Nat Med 2006;12:1286-93

Bröker LE, Huisman C, Span SW, Rodriguez JA, Kruyt FA, Giaccone G. Cathepsin B mediates caspase-independent cell death induced by microtubule stabilizing agents in non-small cell lung cancer cells. Cancer Res 2004;64:27-30

Bustani P, Hodge R, Tellabati A, Li J, Pandya H, Kotecha S. Differential response of the epithelium and interstitium in 
developing human fetal lung explants to hyperoxia. Pediatr Res 2006;59:383-8

Dauger S, Ferkdadji L, Saumon G, Vardon G, Peuchmaur M, Gaultier C, Gallego J. Neonatal exposure to $65 \%$ oxygen durably impairs lung architecture and breathing pattern in adult mice. Chest 2003;123:530-8

Guicciardi ME, Leist M, Gores GJ. Lysosomes in cell death. Oncogene 2004;23:2881-90

Haaften T, Byrne R, Bonnet S, Rochefort GY, Akabutu J, Bouchentouf M, Rey-Parra GJ, Galipeau J, Haromy A, Eaton F, Chen M, Hashimoto K, Abley D, Korbutt G, Archer SL, Thébaud $B$. Airway delivery of mesenchymal stem cells prevents arrested alveolar growth in neonatal lung injury in rats. Am J Respir Crit Care Med 2009;180:1131-42

Huang B, Fu H, Yang M, Fang F, Kuang F, Xu F. Neuropeptide substance $P$ attenuates hyperoxia-induced oxidative stress injury in type II alveolar epithelial cells via suppressing the activation of JNK pathway. Lung 2009;187:421-6

Iwata M, Myerson D, Torok-Storb B, Zager RA. An evaluation of renal tubular DNA laddering in response to oxygen deprivation and oxidant injury. J Am Soc Nephrol 1994;5: 1307-11

Kim YM, Kim TH, Chung HT, Talanian RV, Yin XM, Billar TR. Nitric oxide prevents tumor necrosis factor a-induced rat hepatocyte apoptosis by the interruption of mitochondrial apoptotic signaling through s-nitrosylation of caspase-8. Hepatology 2000;32:770-8

Kroemer G, Dallaporta B, Resche-Rigon M. The mitochondrial death/life regulator in apoptosis and necrosis. Annu Rev Physiol 1998;60:619-42

Layton GT, Harris SJ, Bland FA, Lee SR, Fearn S, Kaleta J, Wood ML, Bond A, Ward G. Therapeutic effects of cysteine protease inhibition in allergic lung inflammation: inhibition of allergic-specific T lymphocyte migration. Inflamm Res 2001; 50:400-8

Lee PJ, Choi AM. Pathways of cell signaling in hyperoxia. Free Radic Biol Med 2003;35:341-50

Mantell LL, Lee PJ. Signal transduction pathways in hyperoxia-induced lung cell death. Mol Genet Metab 2000; 71:359-70

Martin TR, Hagimoto N, Nakamura M, Matute-Bello G. Apoptosis and epithelial cell injury in the lungs. Proc Am Thorac Soc 2005;2:214-20

Martin TR, Nakamura M, Matute-Bello G. The role of apoptosis in acute lung injury. Crit Care Med 2003;31:S184-8

O'Reilly MA, Staversky RJ, Huyck HL, Watkins RH, LoMonaco MB, D'Angio CT, Baggs RB, Maniscalco WM, Pryhuber GS. Bcl-2 family gene expression during severe hyperoxia induced lung injury. Lab Invest 2000;80:1845-54

Perl M, Chung CS, Lomas-Neira J, Rachel TM, Biffl WL, Cioffi WG, Ayala A. Silencing of Fas, but not caspase-8, in lung epithelial cells ameliorates pulmonary apoptosis, inflammation, and neutrophil influx after hemorrhagic sock and sepsis. Am J Pathol 2005;167:1545-9
Rahman I, Mulier B, Gilmour PS, Watchorn T, Donaldson K, Jeffery PK, MacNee W. Oxidant-mediated lung epithelial cell tolerance: the role of intracellular glutathione and NFKb. Biochem Pharmacol 2001;62:787-94

Rama KM, Acarregui MJ, Snyder JM. Differentiation of the alveolar epithelium in the fetal lung. In Lung Growth and Development. (MacDonald JA, ed), 1997, 119-62, Marcel Dekker, New York.

Sanchez-Esteban J, Tsai SW, Sang J, Qin J, Torday JS, Rubin LP. Effects of mechanical forces on lung-specific gene expression. Am J Med Sci 1998;316:200-4

Sanchez-Esteban J, Wang Y, Cicchiello LA, Rubin LP. Cyclic mechanical stretch inhibits cell proliferation and induces apoptosis in fetal rat lung fibroblasts. Am J Physiol Lung Cell Mol Physiol 2002;282:L448-56

Sanchez-Esteban J, Wang Y, Gruppuso PA, Rubin LP. Mechanical stretch induces fetal type II cell proliferation via an epidermal growth factor receptor-extracellular-regulated protein kinase signaling pathway. Am J Respir Cell Mol Biol 2004;30:76-83

Sanchez-Esteban J, Wang Y, Filardo EJ, Rubin LP, Ingber DE. Integrins \{beta\} 1 , \{alpha\} 6 , and \{alpha\} 3 contribute to mechanical strain-induced differentiation of fetal lung type II epithelial cells via distinct mechanisms. Am J Physiol Lung Cell Mol Physiol 2006;290:L343-50

Saraste A, Pulkki K. Morphologic and biochemical hallmarks of apoptosis. Cardiovasc Res 2000;45:528-37

Scavo LM, Ertsey R, Chapin CJ, Allen L, Kitterman JA. Apoptosis in the development of rat and human fetal lungs. Am J Respir Cell Mol Biol 1998;18:21-31

Slater AF, Nobel CS, Orrenius S. The role of intracellular oxidants in apoptosis. Biochim Biophys Acta 1995;1271:59-62

Strasser A, O'Conner L, Dixit VM. Apoptosis signaling. Annu Rev Biochem 2000;69:217-45

Tang PS, Tsang ME, Lodyfa M, Bai X-H, Miller A, Han B, Liu $M$. Lipopolysaccharide accelerates caspase-independent but cathepsin B-dependent death of human lung epithelial cells. J Cell Physiol 2006;209:457-67

Ueda N, Shah SV. Endonuclease-induced DNA damage and cell death in oxidant injury to renal tubular epithelial cells. $J$ Clin Invest 1992:90:2593-7

Wang Y, Maciejewski BS, Lee N, Silbert O, McKnight NL, Frangos JA, Sanchez-Esteban J. Strain-induced fetal type II epithelial cell differentiation is mediated via cAMP-PKA-dependent signaling pathway. Am J Physiol Lung Cell Mol Physiol 2006;291:L820-7

Ward NS, Waxman AB, Homer RJ, Mantell LL, Einarsson O, Du Y, Elias JA Interleukin-6 induced protection in hyperoxic acute lung injury. Am J Respir Cell Mol Biol 2000;22:535-42

Warner BB, Stuart LA, Papes RA, Wispé JR. Functional and pathological effects of prolonged hyperoxia in neonatal mice. Am J Physiol 1998;275:L110-7 